\title{
O CULTO DA DIFERENÇA: IMAGENS DO BRASIL ENTRE EXOTISMO E NACIONALISMO
}

\author{
Luciana Murari \\ Doutoranda Depto. de História-FFLCH/USP
}

\begin{abstract}
RESUMO: Partindo de trabalhos recentes sobre a vida intelectual brasileira pós-1870, este artigo tem por objetivo avaliar a presença do exotismo nas representações da nacionalidade brasileira, entre o movimento romântico e a voga realista. Utilizando-se das idéias de Todorov (1989) a respeito do significado cultural do exotismo, observa-se sua convivência, ainda que contraditória, com a questão nacional, na obra de escritores e críticos voltados para a identificação da singularidade brasileira. Busca-se, assim, acompanhar em linhas gerais os sentidos assumidos pelo exótico na definição da nacionalidade, através do recurso a textos literários e a obras de crítica e historiografia.
\end{abstract}

PALAVRAS-CHAVE: exotismo; Brasil: nacionalismo; romantismo; regionalismo literário.

ABSTRACT: Considering recent works on the post-1870 Brazilian intellectual life, this paper examines the importance of the idea of the exotic in the conceptions of Brazilian nationalism, between Romanticism and Realism. It is taken as reference the development of the concept of the exotic by Todorov, who stresses the contradictory relationship between the national and the exotic. This paper affirms that since the Romantic movement the idea of the exotic has been an essential, although paradoxical, part of the image of Brazilian culture produced by its own writers.

KeYwords: Exotic, Nationalism, Brazilian Literature, Romanticism, Realism.

O exota é assim um ser aureolado por existir numa dimensão que está sempre além da dos homens com quem ele convive. $O$ cultor da diferença encarna ele próprio o princípio e a sedução

hipnótica do inefável. Os homens se estiolam na reprodução massiva da identidade, o exota arde sob a energia do sol perpétuo do mundo do Outro. 
Analisando a vida intelectual brasileira a partir da década de 1870, Schwarcz (1993) utiliza a expressão imperialismo interno para definir uma postura comum entre os estudiosos de formação cientificista ${ }^{1} \mathrm{em}$ relação à problemática racial no Brasil ${ }^{2}$. Esse termo expressa, para a pesquisadora, um processo de apropriação e de aplicação aos estudos sobre o país de conceitos científicos amplamente utilizados pela política imperialista para a legitimação da expansão européia em regiões habitadas por populações de raças tidas como inferiores. No caso brasileiro, essas doutrinas de fundo imperialista, freqüentemente mescladas a conceitos políticos liberais, teriam assim constituído um discurso voltado para o mapeamento das diferenças internas, no sentido da definição de hierarquias políticas e sociais num país cuja formação havia sido significativamente marcada pela escravidão negra.

Não se trata aqui de questionar a validade do termo. Pelo contrário, a idéia do imperialismo interno torna-se objeto de particular interesse quando pensada em função do projeto nacionalista que fundamentava os esforços realizados pelos intelectuais brasileiros do período entre as últimas décadas do século XIX e as primeiras do século XX. Adotando postulados como a inferioridade das raças não brancas, os prejuízos da mestiçagem e a incapacidade do mestiço de assimilar a civilização, eles se dispunham a pensar a construção de uma nação brasileira de acor-

\footnotetext{
${ }^{1}$ Desenvolveu-se a partir de 1868, a princípio na Faculdade de Direito do Recife, um movimento de idéias que conduziu à rejeição do pensamento tradicional da época, sintetizado em torno do ecletismo, do catolicismo e da herança romântica. Daí em diante, uma nova geração, conhecida como a geração de 1870, passou a absorver e divulgar princípios, doutrinas, e escolas européias de pensamento como o materialismo alemão, o positivismo, o darwinismo social e o evolucionismo. Novos modelos teóricos começaram a ser utilizados pela intelectualidade brasileira, tais como as teorias raciais e mesológicas, a criminologia e a psicolo-
}

do com os modelos políticos europeus. Ou seja, a partir de teorias voltadas para o estabelecimento de diferenças e hierarquias, que desembocavam inexoravelmente no descrédito em relação a grande parte do povo brasileiro, deveria ser viabilizada a constituição de uma comunidade política autônoma, unificada e integrada. Esse latente contra-senso entre a afirmação do sentido de nacionalidade e o ideário civilizador de origem européia pode ser acompanhado na obra de importantes intelectuais brasileiros que abraçaram com fervor o paradigma racial: Sílvio Romero, Nina Rodrigues e Euclides da Cunha são alguns deles. As obras desses autores são bastante eloqüentes a respeito dessa noção de descompasso entre os projetos de nação e a formação da população brasileira.

Se o termo imperialismo interno, aplicado à temática etnográfica e à questão nacional, aponta a fonte de alguns dos impasses da intelectualidade do país da virada do século XX, para os interessados na representação da natureza no período surge um termo similar. Estudando um projeto de definição do estilo nacional nas letras brasileiras, Ventura faz uso da expressão auto-exotismo (VENTURA, 1991, p. 38) recorrendo às lentes do exotismo para a representação do próprio meio em que viviam, muitos escritores brasileiros acreditaram poder identificar o que haveria no país de original, em contraste com o Ve-

gia coletiva. A ampla aceitação desses modelos gerou um interesse sem precedentes e uma crença generalizada na ciência, que caracteriza essa geração de intelectuais e que permanece em voga pelo menos até 1914. Daí o termo cientificismo. Ver, a respeito: (SCHWARCZ, 1993), (CANDIDO, 1988) e (WEHLING, 1994). ${ }^{2} \mathrm{~A}$ associação entre as teorias raciais que vinham sendo aplicadas ao Brasil e a legitimação do imperialismo europeu já havia sido realizada na própria época em questão por autores como ARARIPE JR, em 1898 (1978, p. 378-9), e Manoel BOMFIM, em 1905 (1993, p. 243-267). 
lho Mundo, especialmente quando em questão estava a natureza tropical, rica fonte de imagens capazes de simbolizar a singularidade brasileira. Podemos ver a própria expressão auto-exotismo como uma contradição em seus termos, à medida que combina o olhar voltado para aquilo que é estrangeiro e a percepção de si mesmo. Essa problemática já havia sido apontada por Antonio Candido, que identificou, a propósito do romantismo brasileiro, um persistente exotismo, que eivou a nossa visão de nós mesmos até hoje, levandonos a nos encarar como faziam os estrangeiros, propiciando, nas letras, a exploração do pitoresco no sentido europeu, como se estivéssemos condenados a exportar produtos tropicais também no terreno da cultura espiritual (CANDIDO, 1981, p. 324).

O exotismo configurou a concepção de muitos escritores brasileiros a respeito da identidade ou originalidade do país, especialmente quando em questão estava a natureza e as peculiaridades de uma sociedade tropical. Esse exotismo a nossos próprios olhos é, assim como a idéia do imperialismo interno anteriormente citada, inseparável dos projetos nacionalistas que animaram a intelectualidade brasileira, em especial após a independência política do país. A relação entre nacionalismo e exotismo é uma temática que, acreditamos, pode iluminar algumas das singularidades da literatura e, de modo geral, da cultura brasileira, desde o movimento romântico, especialmente quando em questão está o olhar do escritor em direção à base física e natural do país. Da mesma forma como a temática do imperialismo interno pode conduzir a algumas das discussões centrais sobre a intelectualidade brasileira e suas concepções a respeito da população do país, nos propomos a traçar algumas relações entre o auto-exotismo e a representação do nacional na literatura brasileira.

\section{Um elogio no desconhecimento}

Em carta a Affonso Taunay datada de 28 de setembro de 1920, Capistrano de Abreu anota um exemplo jocoso do desejo pelo exótico brasileiro: "Tivemos chuva e reis da Bélgica e Congo. A chuva parece entrar em férias; sem grande alvoroço. Os reis continuam não muito satisfeitos. Não encontraram o Brasil de seus sonhos. Queriam ver mata, sertão, índios; encontraram engrossadores, toma-larguras e mendigos de comendas. Defendem-se, condecorando chauffeurs e abreviando uma semana a camisola-de-força (ABREU, 1969, p. 315). É certamente mais fácil definir esse Brasil dos sonhos, mata, sertão, índios, como fez Capistrano tão sumariamente, que definir o exotismo. Para nossos propósitos, acompanharemos a definição desenvolvida por Todorov (1989), especialmente porque este autor estuda o exotismo em contraposição ao nacionalismo. Ambos os fenômenos constituem, segundo ele, uma forma de relativismo, ou seja, têm como objeto não uma cultura determinada, dotada de significação própria, mas algo que é construído apenas em relação ao olhar daquele que observa. No caso do nacionalismo, notadamente na perspectiva do nacionalismo político, o observador considera que seu país de origem deve ser valorizado em função de sua superioridade em relação aos demais, superioridade determinada simplesmente porque este é o seu país, e nenhum outro. O exota, ao contrário, encontra os mais altos valores numa cultura à qual ele não pertence e é esse não-pertencimento que estabelece o interesse e a valorização de outra cultura. Ambos os conceitos, nacionalismo e exotismo, se referem, portanto, a posturas simplesmente relativas, uma vez que o objeto de interesse só se constrói comparativamente ao olhar daquele que observa e estabelece um julgamento de valor.

Preferir o outro a si próprio é uma postura sobretudo abstrata, lembra Todorov. O outro é julgado superior não por seu conteúdo peculiar, mas apenas pela maneira como proporciona a crítica dos valores per- 
tinentes à cultura do observador. Outras culturas convertem-se, dessa forma, em um ideal, o ideal da alteridade. Esse culto da diferença apóia-se, contudo, em aceitar que a única identidade do outro seja a negação do universo do mesmo. Por isso, a lógica do exotismo se baseia no contraste e na inversão, operados a partir de polarizações: o simples e o complexo, o selvagem e o civilizado, o natural e o artificial, o espontâneo e o contrafeito, e assim por diante. O exotismo existe, portanto, apenas à medida que esse outro que se cultua permaneça desconhecido, pois o conhecimento poderia dotá-lo de significações particulares e estranhas à sua condição de espectro. As maiores virtudes das terras exóticas são a distância e a ignorância a respeito delas, pois é isso que as torna passíveis de idealização. Todorov observa, assim, o quão pouco auspicioso é esse elogio do exota. Em suas palavras, la connaissance est incompatible avec l'exotisme, mais la méconnaissance est à son tour inconciliable avec l'éloge des autres; or, c'est précisément ce que l'exotisme voudrait être, un éloge dans la méconnaissance. Tel est son paradoxe constitutif (TODOROV, 1989, p. 298).

Se o próprio exotismo é por natureza paradoxal, o que poderia ser dito, então, do auto-exotismo identificado na cultura brasileira? Sem se considerar essa manifestação mera cópia de modelos culturais estrangeiros, as origens da representação exótica do Brasil podem ser buscadas no imaginário europeu e na visão ambígua que nele se formou a respeito do Novo Mundo. A América tornou-se, desde sua descoberta, objeto privilegiado dos escritos de viajantes, naturalistas e missionários, que elaboraram descrições, ainda que permeadas de fantasia, de algumas das peculiaridades físicas e naturais do continente. Com a colonização do Novo Mundo, e também a exploração do continente africano, surgiu aos olhos europeus uma humanidade definida como selvagem ou exótica. Esses povos eram vistos, por muitos de seus observadores, como os habitantes de um mundo natu- ral dotado de igualdade e liberdade, ao contrário da vida artificial e desigual do Velho Mundo. Esse elogio do selvagem, que caracterizou a presença da América no imaginário europeu principalmente até o século XVIII, abriu espaço para a valorização do Novo Mundo. Projetou-se sobre ele a crença no retorno da idade de ouro, operada por meio de associações entre os costumes do homem americano e os dos ancestrais do homem europeu. A partir dessa idealização do selvagem, chegar à América tornava-se uma forma de acesso às origens, o que levou a caracterizá-la como primitiva. Essa primeira visão exótica do novo continente alimentou-se do mito do bom selvagem que, em sua vida natural, espontânea e harmoniosa em relação ao mundo que o cercava, convertia-se num poderoso referencial para a crítica da sociedade européia. É a crítica que dá o tom desse elogio ao americano, que não se define por seus próprios traços, mas por sua alteridade, sua oposição ao homem europeu e à experiência da vida civilizada, ou seja, seu exotismo. O objeto deste debate é, portanto, menos o homem selvagem do que o civilizado, que vê em jogo sua própria concepção de história e de humanidade. Essa visão da América exótica foi bastante fértil, mas dividiu terreno, desde o início, com a condenação da barbárie e a defesa da superioridade da civilização (VENTURA, 1991, TODOROV, 1989).

Em meados do século XVIII, no entanto, num momento em que o conhecimento e a exploração do novo continente haviam operado avanços mais significativos, a América e os americanos tornaram-se objeto de teorias científicas sistemáticas a propósito de sua suposta inferioridade, debilidade ou imaturidade, a partir da publicação da História Natural de Buffon e da divulgação dos escritos de De Pauw. Inaugurou-se, assim, a chamada disputa do Novo Mundo, que opôs frontalmente Europa e América, atraiu a atenção de personagens influentes na filosofia, na política, na literatura e na ciência natural, e moldou durante longo tempo a representação do novo conti- 
nente, dividido entre detratores sistemáticos e ardorosos partidários. As relações entre alguns dos frutos dessa polêmica e a ascensão do sentimento nativista nos países americanos são por vezes bastante nítidas: Gerbi demonstra como a defesa do Novo Mundo contra as acusações dos partidários das teorias de Buffon e De Pauw dá origem a algumas das primeiras manifestações do orgulho americano nas colônias hispânicas (GERBI, 1996).

Alguns dos topoi da disputa do Novo Mundo continuaram, mesmo após a dissolução da polêmica, no final do século XIX, presentes no discurso sobre os países americanos. Um deles se organiza em torno dos sentidos de juventude e velhice. À América foi lançada tanto a condenação por sua extrema juventude, ou imaturidade, quanto por sua antigüidade. A Europa, por sua vez, foi inúmeras vezes definida como um continente a caminho da decrepitude, devido à limitação territorial e ao virtual esgotamento de seus recursos naturais, enquanto ao Novo Mundo foi atribuído o sentido de futuro, de redenção e de vanguarda da humanidade. Também deve-se observar que, do lado americano, se o recurso ao passado permaneceu durante longo tempo interdito, pelo fato de ser este passado muito pouco assimilável a qualquer forma de progresso ou civilização, o entusiasmo pelos valores físicos e naturais da América tornou-se fonte de esperança no futuro e réplica constante às acusações européias. Outro tema que surge na polêmica e permanece por longo tempo identificável no discurso sobre a América é o da oposição entre a paisagem americana, reconhecidamente grandiosa, generosa e exuberante, e a sociedade que ocupava o novo continente. Ou seja, a América permanecia encerrada dentro dos domínios da geografia e da natureza, enquanto o domínio da história e do progresso social continuava dominado pela Europa. A longevidade dessa temática da oposição entre Novo e Velho Mundo se explica pelas questões de fundo que, segundo Gerbi, permearam toda a história da polêmica, questões sempre passíveis de atualização: o progresso, o valor da civilização, o primitivismo, as relações ideais entre os dois continentes, os sentidos de humanidade e de história (GERBI, 1996, p. 103).

O problema que se coloca diz respeito a até que ponto a discussão brasileira sobre a essência nacional seguiu os rastros da dúbia visão européia sobre a América, que persiste, por exemplo, na representação exótica de sua natureza. A viabilidade da construção de uma sociedade autônoma no mundo tropical dependia da afirmação de sua diferença fundamental em relação ao padrão europeu de cultura e de história, diferença percebida como originalidade, demonstração de independência e identidade cultural própria. As visões do Brasil foram, contudo, assentadas em modelos e aportes teóricos de origem européia, constantemente retrabalhados para atender às particularidades da sociedade brasileira, tais como sua formação humana especialmente quando em questão estava a miscigenação - e suas condições naturais, ou seja, o ambiente tropical, em suas especificidades climáticas e paisagísticas. Não era possível, no entanto, adequar completamente os modelos europeus de conhecimento aos objetos de interesse: a percepção de um desajuste entre essas matrizes culturais e a realidade brasileira que se pretendia representar e compreender explica o recurso a expressões paradoxais como imperialismo interno e auto-exotismo.

\section{Sublime nos livros, desagradável na realidade}

A difusão do imaginário do exótico na cultura brasileira do século XIX se deve, em grande parte, à influência da estética romântica, cuja divulgação no país é paralela às primeiras tentativas mais importantes de definição da essência ou originalidade da nação brasileira, a partir de sua independência política. O programa romântico brasileiro se deixou impregnar, desde suas origens, por esta confluência entre nacionalismo e exotismo. No caso europeu, tanto o 
nacionalismo quanto o exotismo se enquadram num programa de crítica à modernidade, como observam Löwy e Sayre (1995). Na visão desses autores, o fenômeno romântico, em suas formas múltiplas e muitas vezes contraditórias, pode ser sintetizado em torno da crítica aos valores da modernidade, a partir de uma percepção da perda, no mundo moderno, de valores humanos próprios às sociedades pré-industriais. Daí se compreende o desejo romântico de retorno ao passado nostálgico, onde seria possível recuperar virtudes que faltam à realidade presente. É na adoção de um sistema de valores que tem como referência um ideal do passado que reside a especificidade da crítica romântica à modernidade. Em busca desse passado perdido, o romântico abandona o mundo burguês, renunciando à vida urbana em favor da vida rural, renegando os países modernos em favor dos lugares exóticos, onde o passado primitivo tenha sido de alguma forma conservado. A viagem do romântico é uma viagem de retorno aos mananciais da criação, da sensibilidade e da espontaneidade, que nas sociedades modernas já se teriam exaurido por completo. $\mathrm{O}$ deslocamento no espaço tem, por isso, o mesmo sentido de um deslocamento temporal, pois o que se busca é recuperar o passado.

Ao lado do privilégio conferido pelo romantismo à subjetividade do indivíduo, valor eminentemente moderno, o principal valor positivo do romantismo é a totalidade, expressa por exemplo pela idéia de comunidade, em oposição ao individualismo. Portanto, o romântico almeja se inserir na natureza, na humanidade, ou em uma coletividade ancestral como a nação, de forma a restabelecer laços de solidariedade e vínculos sociais perdidos. Tanto o nacionalismo - aqui especialmente em sua forma cultural, fundamentada pelas tradições imemoriais e pelo espírito do povo quanto o exotismo respondem, no programa romântico, ao desejo de regresso a formas de vida tidas como mais autênticas e espontâneas que a modernidade. Ao mesmo tempo, ambos conduzem ao estabe- lecimento de uma relação mais profunda com o mundo natural.

$\mathrm{Na}$ comunhão com a natureza, dessacralizada e posta em relação direta com a subjetividade humana, o romantismo europeu encontrou um caminho para a auto-reflexão, por meio do qual o indivíduo poderia transcender as limitações e atribulações da vida concreta e presente, voltando-se para a reflexão e a crítica à sociedade. Paralelamente, a natureza se tornou um espaço privilegiado para o discurso do estado nacional, operado por uma observação de fundo científico. É esse mesmo olhar observador o descrito por Janice Theodoro a partir dos escritos de Hercules Florence, olhar caracterizado sobretudo por seu distanciamento em relação ao objeto. Tratava-se de ordenar, hierarquizar e organizar a natureza, operando escolhas e distinções de acordo com uma intenção de controle da realidade americana a partir do olhar europeu. A natureza americana foi, então, moldada de forma a se tornar passível de interpretação científica, elemento necessário para sua transformação em objeto de uso (THEODORO, 1996). A visão romântica do mundo natural se organiza em torno desses dois pólos, que idealmente vivem em constante comunicação: incentivo à auto-reflexão transformadora e à expansão da subjetividade, por um lado, e objeto da observação científica, por outro.

No romantismo brasileiro, contudo, essa dialética entre observação e auto-reflexão estabeleceu uma relação com a natureza que se apoiou obrigatoriamente no exotismo (LIMA, 1984, p. 135). Se na perspectiva do homem europeu o exotismo era uma forma de libertação da realidade objetiva e presente por meio do elogio do outro, notadamente o primitivo, sua adoção sem restrições pelo romantismo brasileiro dependia do uso do mesmo olhar distanciado, característico do estrangeiro, do viajante, do curioso. Olhar que se apóia, sobretudo, no alheamento. A adoção da perspectiva do exótico na representação da natureza indica que no Brasil o culto da observação não se convertia 
em crítica à ordem instituída pois, ingressando no país como nova onda civilizadora, ${ }^{3}$ o romantismo contava com o favorecimento do estado imperial. Assim, ao renunciar às conseqüências libertadoras da reflexão, $\mathrm{o}$ romântico brasileiro a substituiu pelo deslumbramento frente à exuberância da natureza, cenário grandioso de suas lamentações sentimentais. No Brasil, portanto, a prática da observação, revestida de sentimentalismo nostálgico e melancólico, se impôs à auto-reflexão. Tratava-se, certamente, de compensar a estreiteza e atraso da vida social através do recurso à grandiosidade e exuberância da natureza, tópico recorrente na disputa do Novo Mundo. Esse contraste denuncia, certamente, a referência necessária e constante à Europa. Os intelectuais europeus que se interessaram pelas letras brasileiras foram os primeiros a apontar a necessidade de que a literatura do país voltasse seus olhos para a natureza tropical ${ }^{4}$. Tal opção estética correspondia, por outro lado, à afirmação da autonomia do recém-nascido império, que assim demarcava nitidamente sua diferença em relação à Europa.

$\mathrm{O}$ instinto de nacionalidade, na expressão de Machado de Assis, dominou a reflexão romântica sobre a literatura brasileira desde suas primeiras manifestações. Em busca das origens das letras nacionais, alguns dos nossos românticos empreenderam até mesmo curiosas investigações a respeito da exis-

\footnotetext{
${ }^{3}$ Lembre-se que nos primeiros anos do século XIX, mesmo antes da independência política, o Brasil, e em particular a Corte do Rio de Janeiro, já vinha experimentando um processo contínuo de ocidentalização, que consistia sobretudo na adoção de um conjunto de idéias e hábitos tidos como civilizados. A literatura fez parte do processo de formação dessa consciência civilizadora, assumindo um caráter político nítido.

${ }^{4}$ A solução pelo exotismo - o elogio do outro e do desconhecido - deve-se em parte à influência de críticos como o brasilianista francês Ferdinand Denis, para o qual a única fonte possível de originalidade nas letras brasileiras era a contemplação da natureza, somada à observação dos costumes (Candido, 1981).
}

tência de poesia entre as tribos indígenas antes da chegada dos portugueses. Se o indígena romântico traz em si os traços da civilização que ainda não conhece, mas que é capaz de anunciar, ele representa também o recurso à narrativa mítica. Ao lado do passado indígena, a grande especificidade brasileira - em relação ao europeu, certamente - era a natureza tropical, que já havia chamado a atenção de inúmeros viajantes e cientistas estrangeiros, em cujos relatos os escritores brasileiros vão muitas vezes encontrar inspiração. Esses relatos assumem, freqüentemente, um papel de mediação e de justificação para que todos os olhares se voltassem para a paisagem natural. Fazer da natureza a principal fonte da originalidade das letras brasileiras tornou-se um imperativo, pois era essa a temática que poderia diferenciá-la da européia, definir sua autonomia, e fazer dela objeto de interesse. Alimentando-se da ênfase romântica na prática da observação científica, na anotação minuciosa, na procura da perfeição do detalhe, o descritivismo paisagístico incorporou-se, assim, à literatura brasileira, dentro de um modelo pitoresco e indubitavelmente exótico que tinha como interlocutores preferenciais os viajantes estrangeiros, e como modelos os seus relatos 5 .

Os personagens que povoavam essa natureza passível de ser reconhecida como brasileira incorporavamse sem fissuras ao cenário. O primado da observação geralmente não conduzia, contudo, à experiência direta ou a um mergulho do escritor nos ambientes que buscava descrever. O romantismo brasileiro construiuse no domínio da natureza e do mito, não no da histó-

\footnotetext{
${ }^{5}$ Flora Süssekind demonstrou como no Brasil só apenas a partir da década de 1850 começou a ser efetivada uma separação nítida entre a narração ficcional e os relatos de viagem, que vinham exercendo uma influência fundamental na formação da figura do narrador, na construção de uma imagem do Brasil e nas formas de descrição da natureza brasileira (Süssekind, 1990).
} 
ria, da experiência e dos acontecimentos. Privilegiouse a descrição social constituída como observação objetiva de um mundo exterior, ascético, que não se referenciava no passado histórico, o que evitava também o enfrentamento do problema do atraso brasileiro (CARVALHO, 1989). A proposta literária afastouse, assim, do sentido da recuperação das tradições, da constituição de uma memória e de uma função de transformação social. Desviando-se das noções de ruptura ou mesmo de uma recuperação do passado histórico perdido, instituiu-se, pelo contrário, a visão observadora da cena brasileira exótica - a paisagem, os costumes - capaz de representar a essência nacional.

A ingenuidade do programa romântico de exaltação da paisagem brasileira - uma paisagem brasileira por excelência - conduziu ao divórcio entre descrição e experiência que despertou a ira de Macário no célebre texto de Álvares de Azevedo:

PENSEROSO: Esperanças, e esse Americano não sente que ele é filho de uma nação nova, não a sente o maldito cheia de sangue, de mocidade e verdor? Não se lembra que seus arvoredos gigantescos, seus oceanos escumosos, os seus rios, suas cataratas, que tudo lá é grande e sublime? Nas ventanias do sertão, nas trovoadas do sul, no sussurro das florestas à noite, não escutou nunca os prelúdios daquela música gigante da terra que entoa à manhã a epopéia do homem e de Deus? Não sentiu ele que aquela nação infante que se embala nos hinos da indústria européia como Júpiter nas cavernas do Ida ao alarido dos Coribantes - tem um futuro imenso?

MACÁRIO: Falam dos gemidos da noite no sertão, nas tradições das raças perdidas na floresta, nas torrentes das serranias, como se lá tivesse dormido a menos uma noite, como se acordasse procurando túmulos, e perguntando como Hamleto no cemitério a cada caveira do deserto o seu passado.

Mentidos! Tudo isso lhes veio à mente lendo as páginas de algum viajante que esqueceu-se talvez de contar que nos mangues e nas águas do Amazonas e do Orenoco há mais mosquitos e sezões do que inspiração; que na floresta há insetos repulsivos, reptis imundos; que a pele furta-cor do tigre não tem o perfume das flores... que tudo isso é sublime nos livros, mas é soberanamente desagradável na realidade!” (AZEVEDO, 1984/1855, p. 100 e 103)
Este afastamento em relação à experiência, denunciado por Macário, está relacionado à busca, empreendida pelo romantismo brasileiro, de uma essência atemporal, da narração de uma origem na forma da gênese mítica da nacionalidade. O narrador romântico vestiu-se, para isso, da alienação em relação ao mundo exterior, concentrando-se em algum lugar do passado onde seria possível alcançar a essência da nacionalidade. O Brasil foi, desta forma, descrito e narrado de acordo com uma imagem pré-construída, tornando-se objeto de um contínuo ato de colecionar paisagens e espécimens da natureza, o que fez com que o escritor assumisse, assim, o alheamento de um estrangeiro. É o que Süssekind definiu como a sensação de não estar de todo, expressão que traduz o olhar de um escritor viajante, estrangeiro, apenas de passagem por um cenário que não o absorve (SÜSSEKIND, 1990, p. 21). Pelo contrário, é ele que pretende absorver a paisagem, por meio de procedimentos padronizados de classificação, exclusão, ordenação e organização. A natureza dos românticos é, assim, um mundo unificado, edênico e utópico, essencialmente a-histórico.

Embora dominante e paradigmática, essa tendência não foi exclusiva, especialmente à medida que $o$ movimento literário avançava no país e começava a se liberar do significativo conteúdo de artificialidade da fórmula romântica de nacionalidade na literatura brasileira, denunciado por Álvares de Azevedo. Exemplo disso é a sensível releitura do conceito de literatura nacional elaborada por Machado de Assis, autor urbano e pouco afeito ao cânon das letras tipicamente brasileiras. De acordo com Machado, a nacionalidade não deveria se manifestar, na literatura, por meio de escolhas temáticas - indianismo, regionalismo, exaltação da paisagem - e nem de qualquer outro elemento explícito. O traço distintivo de uma literatura estava sobretudo em sua forma específica de sensibilidade, um modo de sentir particular do escritor que inevitavelmente o inseria em um deter- 
minado conjunto de significados compartilhados socialmente:

Devo acrescentar que neste ponto manifesta-se às vezes uma opinião, que tenho por errônea: é a que só reconhece espírito nacional nas obras que tratam de assunto local, doutrina que a ser exata, limitaria muito os cabedais da nossa literatura.(...)

Não há duvida que uma literatura, sobretudo uma literatura nascente, deve principalmente alimentar-se dos assuntos que lhe oferece sua região, mas não estabeleçamos doutrinas tão absolutas que a empobreçam. O que se deve exigir do escritor antes de tudo, é certo sentimento íntimo, que o torne homem de seu tempo e de seu país, ainda quando trate de assuntos remotos no tempo e no espaço (ASSIS, 1955/1873, p. 134-135)

Definindo o instinto de nacionalidade como o primeiro traço característico da literatura brasileira, Machado demonstra a centralidade do tema, e também aponta algumas de suas reformulações e revisões num momento em que se observava a ascensão do padrão cientificista da geração de 1870 . Se por um lado essa renovação, programaticamente anti-romântica, trouxe algumas novidades para a discussão a respeito da nacionalidade na cultura brasileira, por outro é necessário demarcar algumas das continuidades entre os dois processos culturais, romantismo e naturalismo, muitas vezes distintos de forma excessivamente rígida. Na segunda metade do século XIX, a idéia de progresso se afirmava entre a elite intelectual do país, em oposição ao padrão a-histórico que vinha até então caracterizando sua representação da realidade nacional. O imperativo de construção de uma identidade brasileira continuava na ordem do dia, somando-se à tarefa de superação da tradição colonial, e recebendo novo impulso após o surgimento da voga naturalista. Vimos anteriormente como uma postura observadora da realidade, baseada na descrição e no distanciamento do viajante, impôs-se graças a uma concepção romântica que conduzia a uma internalização do exotismo. Embora reformulado e vestido com nova roupagem, o exotismo não abandonou as concepções realistas e naturalistas na literatura brasileira.

\section{Indulgência galhofeira}

Um exemplo significativo do espaço de convivência e de continuidade entre romantismo e naturalismo no Brasil é certamente a obra do crítico literário Araripe Jr, que procura a fonte da originalidade brasileira a partir de um modelo positivista ${ }^{6}$. As teorias científicas do determinismo mesológico afirmavam a influência decisiva exercida pelas forças da natureza sobre as possibilidades de progresso e civilização das sociedades humanas. Tal influência das condições naturais faria com que os países tropicais se tornassem radicalmente distintos da Europa, e demandava que a história da colonização desses países pelo homem branco fosse escrita a partir do seu processo de aclimatação no novo continente. A peculiaridade dos países tropicais é definida, sobretudo, pelo império das condições ambientais sobre as condições sociais, o que, de acordo com os modelos deterministas, tornaria esses países debilitados para o exercício de funções como a racionalidade, o domínio do intelecto e a capacidade de organização social, frente a uma exaltação exagerada dos sentidos. O que fez Araripe Jr foi utilizar-se dos julgamentos negativos da ciência européia a respeito dos países tropicais, convertendo essa negatividade em originalidade, ou melhor, em estilo. De forma diversa da que era praticada pela literatura romântica brasileira, em que a natureza

${ }^{6}$ Trata-se aqui da obra do historiador positivista Henry Thomas Buckle, que teve notável repercussão no Brasil, e que também influenciou, principalmente nas últimas décadas do século XIX, autores brasileiros como Euclides da Cunha, Sílvio Romero e Capistrano de Abreu. A respeito de sua teoria, ver WEHLING (1992), VENTURA (1991) e MURARI (1996). 
surgia sobretudo como cenário a ser observado e descrito, para esse crítico a influência do ambiente residiria sobretudo na conformação de um novo homem, que sob as condições tropicais viria adquirir características essencialmente opostas às do europeu: a desordem impõe-se à correção, o arrebatamento à frieza, o sensualismo à razão, a embriaguez de luz à sobriedade do europeu. Em suas palavras,

O tropical não pode ser correto. A correção é o fruto da paciência e dos países frios; nos países quentes, a atenção é intermitente. Aqui, onde os frutos amadurecem em horas, aonde a mulher rebenta em prantos histéricos aos 10 anos, aonde a vegetação cresce e salta à vista, aonde a vida é uma de viço, aonde tudo é extremoso, e extremados os fenômenos; aqui, aonde o homem sensualiza-se até com o contato do ar e o genesismo terrestre assume proporções enormes, vibrando eletricidade, que em certas ocasiões parece envolver toda a região circundante em um amplexo único, fulminante, - compreende-se que fora de todas as coisas a mais irrisória pôr peias à expressão nativa e regular o ritmo da palavra pelo diapasão estreito da retórica civilizada, mas muito menos expansiva" (ARARIPE JR, 1978/1888, p. 126).

Se por um lado a teoria de Araripe supera o simplismo da fórmula romântica de representação da natureza tropical, convertendo-a de objeto em verdadeira substância do estilo literário, por outro não faz senão renovar a prática do exotismo romântico. Em sua teoria, o que define o Brasil e seu estilo literário é a tropicalidade, e o fato de que as condições geográficas do país são variadas não muda essa condição ${ }^{7}$. Se dentro do próprio país as diferenças são muitas vezes apagadas para a construção de uma unidade onde a diversidade é inegável, é significativo que,

\footnotetext{
${ }^{7}$ Um texto do crítico Sílvio Romero exemplifica muito bem a forma como muitas vezes era abordada a diversidade geográfica do Brasil: a configuração topográfica e geológica do país não permite que seo tome como um corpo bruto, confuso, indistinto, marcado por uma só característica mesológica, mas o verdadeiro Brasil está contido na zona tórrida (ROMERO, 1943/1888, p. 74) (grifo acrescentado).
}

fazendo uso dos escritos de um médico francês a respeito dos processos de aclimatação do europeu na Martinica, Araripe observe que Antilhas ou Rio de Janeiro são uma e a mesma coisa (ARARIPE JR., 1978/1888, p. 125). É possível fazer aqui um paralelo com o que observa Todorov a respeito dos viajantes franceses, para os quais todos os primitivos se parecem, sejam eles de qualquer região ou continente, pois o que importa é que, para o exota, eles representam o oposto de seu país natal (TODOROV, 1989, p. 304).

A teorização de Araripe retoma, portanto, a prática do exotismo, aliando o tom romântico de exuberância e entusiasmo às teorias científicas então em voga. Ela tem certamente muitos méritos, principalmente por reverter o notório pessimismo de sua geração que, assimilando as variadas correntes do naturalismo europeu, tendia a abraçar doutrinas como a inferioridade das populações mestiças e a inviabilidade do progresso nos países quentes. Por outro lado, o crítico recorre a tópicos que lembram a disputa do Novo Mundo, como a oposição entre o domínio da geografia, ocupado pela América, e o domínio da história, pertencente à Europa. Ele recorre também ao elogio à juventude da América - à qual pertence o futuro - frente à decadência e ao passadismo europeus: um cadáver não se observa do mesmo modo que um ser que ofega de vigor (ARARIPE JR, 1978/1888, p. 127).

O exotismo persistiu após a superação do modelo romântico na literatura brasileira não apenas pela via dos louvores à originalidade tropical, convertida em estilo, como se lê em Araripe Jr, mas também pela continuidade da perspectiva de observação externa da realidade. Apesar de um processo de contínua dinamização do pensamento social, graças à influência das concepções evolucionistas, que possibilitaram aos intelectuais o vislumbre de um futuro previsível a partir da análise do presente, ao imaginário e a possíveis projetos de intervenção impôs-se, novamente, a prática observadora. Esta se lança sobre uma sociedade independente e anterior ao escritor, que empreende uma 
crítica externa e, como bem observa Carvalho (1989), dirige um olhar aristocrático sobre o ambiente exterior, agora certamente dotado de maior realismo. Portanto, a atitude de transcendência estabelecida pelo escritor romântico em relação a seu objeto, a realidade brasileira, não desvaneceu com a emergência dos naturalismos. Pelo contrário, os novos paradigmas, racionais e históricos, possibilitaram o fortalecimento da postura de observação, o que, segundo Luís Costa Lima, tornou extremamente facilitada a transição do romantismo para o realismo no Brasil (LIMA, 1984, p. 146). Frente a uma herança romântica atemporal, a emergência dos naturalismos soube implantar o sentido de transformação social. Foi possível então o surgimento de uma consciência histórica oposta à idéia de natureza que fundamentava o edenismo romântico. A transformação social é concebida sob a mediação da ciência, tornando possível o empreendimento de missões civilizadoras voltadas para a inserção das populações marginais na temporalidade do progresso e da civilização ${ }^{8}$.

O paradigma científico veio tornar mais dinâmicas as concepções a respeito da sociedade brasileira, adicionando a elas a possibilidade de controle do homem sobre a realidade factual e objetiva ou, na significativa expressão de Euclides da Cunha, o império do homem sobre as coisas (CUNHA, 1907/ 1919, p. 302). O olhar que se lança sobre essa realidade, agora com as lentes da história e da razão, é novamente um olhar distanciado em relação ao objeto. O que muda é que esse universo estrangeiro faz agora parte da racionalidade e da história, e não se funda

\footnotetext{
${ }^{8}$ A transformação social por via da ciência e da técnica foi a tônica de diversas incursões empreendidas por cientistas e pela elite política, direcionadas às populações mais atrasadas do país. Dentre essas missões, podemos citar as intervenções em Canudos e no Contestado, as campanhas sanitaristas, as viagens de Rondon pela Amazônia, a reforma urbana do Rio de Janeiro. Ver, a respeito, CARVALHO (1991).
}

no passado, mas em aspirações de um futuro onde o domínio da ciência, da técnica e da razão se imponha por completo. Apesar de inegavelmente envolvido nesse meio social, o escritor o descreve com as lentes do primitivismo.

Embora a literatura pós-romântica tenha favorecido a temática urbana, a representação da realidade do mundo rural cristalizou-se, nas primeiras décadas do século XX, na forma do prolífico gênero regionalista. Como bem definiu Antonio Candido, o regionalismo naturalista conduziu ao total alheamento do homem, que passa a fazer parte da paisagem natural, numa narrativa que privilegia sobretudo o exótico e o pitoresco (CÂNDIDO, 1981, p. 212-3). Transformado em tipo humano, o homem existe apenas em função de suas particularidades regionais, definidas por traços - aparência, fala, gesto, modo de vida, comportamento, crenças - que determinam seu caráter e o tornam típico. O regionalismo é um terreno privilegiado para a expressão do gosto pelo exótico, voltado aqui para a descrição de cenários, paisagens, personagens e modos de vida remotos e alheios, que são definidos em função de sua distância em relação ao universo moderno, do qual foram resguardados pelo isolamento. É o cálculo de diferenças e de distâncias que move a prosa regionalista, o que aprofunda o primado da observação sobre a imaginação já vigente desde o romantismo, e ao qual se soma a imposição da objetividade à subjetividade. Trata-se da conversão da romântica cor local em um gênero bem definido, que se volta não tanto para as diferenças externas - as especificidades brasileiras frente aos estrangeiros - como para as diferenças internas - o olhar do escritor brasileiro sobre a excentricidade das regiões mais atrasadas do país em relação a um universo cultural onde a modernidade já havia imposto seus valores.

Esse procedimento aprofunda a prática, descrita anteriormente, de distanciamento entre o escritor e seu objeto, em relação ao qual ele estabelece uma 
visão nostálgica, por vezes melancólica, porém nunca de todo afastada do que Lúcia Miguel-Pereira definiu como indulgência galhofeira (MIGUEL-PEREIRA, 1957, p. 34). Tratava-se de narrar os universos rurais antes que eles se extinguissem por completo, registrando por escrito tradições orais, no momento em que elas começavam a experimentar a real ameaça de desaparecimento em função dos processos de urbanização e de expansão das instituições de ensino. Absorvendo o mundo rural, a prática literária urbana contribui para a inserção dessas realidades regionais, devidamente filtradas e homogeneizadas, dentro da cultura nacional. O regionalismo literário brasileiro, ao possibilitar a integração da cultura popular, contribui assim para a constituição da narrativa da gênese nacional, explicitando sua formação e composição (RAMA, 1985).

A problemática que se apresenta é, contudo, eminentemente urbana. Exemplo disso é a sensação de tédio que freqüentemente acompanha o narrador regionalista em suas incursões pelo meio rural, definido como um lugar de vida vazia, onde o curso do tempo é moroso, em referência, certamente, ao ritmo acelerado da cidade ${ }^{9}$. Os atrativos dessas verdadeiras viagens etnográficas pelo Brasil rural não residem, contudo, apenas no que seus cenários e personagens poderiam oferecer como pitoresco ou curioso para o homem da cidade. Em um momento de cosmopolitismo e modernização, ainda que incipiente, o retorno à natureza e à vida rural foi muitas vezes definido como uma busca de autenticidade, um encontro com uma verdade nacional soterrada pela vida artificial, porque estrangeirizada, da cidade, numa visão dicotômica tão característica da observação do exótico. O relato de um escritor regionalista é eloqüen-

\footnotetext{
${ }^{9}$ Nesse ponto é paradigmática a novela Vida Ociosa, de Godofredo Rangel (1917), inteiramente construída a partir das sensações de ócio, de tédio, de lentidão.
}

te: Eu nada sabia, e ele, o rude agricultor e campeiro, era mais digno da América do que eu. Ele era brasileiro e eu um manequim da Europa, deslocado do meio em que nasci, onde vivia e respirava, apesar de conhecer várias línguas, história, filosofia e quejandas matérias (apud MIGUEL-PEREIRA, 1957, p. 35). Parece ser justamente o distanciamento - tanto geográfico quanto cultural - que dá condições ao escritor de reconhecer a validade desse outro universo e empreender seu trabalho de intérprete: o mundo rural, espaço da legítima expressão do ser brasileiro, deve ser traduzido por e para o homem urbano, e é essa tradução a garantia de sua sobrevivência como reservatório de valores autênticos, livres da contaminação da cultura estrangeira, e ameaçados de extinção.

Assim como o discurso sobre o mexicano nada tem, como observa Bartra, de especificamente mexicano, também essa nostalgia rural que nutre as narrativas regionalistas brasileiras nada tem de especificamente brasileiro, ou mesmo latino-americano. Todas as sociedades que se definiram, desde a Revolução Francesa e a Revolução Industrial, como sociedades seguidoras, tiveram sua vida cultural polarizada entre a imitação dos países adiantados e a crítica aos valores estrangeiros, associada à busca das fontes de energia de sua própria cultura nativa (BENDIX, 1996). No caso brasileiro, temos certamente que relativizar essa polarização, uma vez que entre nós o impulso nacionalista sempre se nutriu da inspiração dos modelos europeus. Embora a retórica regionalista expresse essa polaridade, é difícil acreditar que algum desses escritores tivesse realmente proposto um retorno à vida primitiva e qualquer forma de renúncia à modernização.

A partir daí, são muitas as similitudes entre o caso brasileiro e o observado por Bartra a respeito do México: o mito essencial do discurso nacionalista modernizador nos dois países pode ser muito bem definido como o mito do paraíso subvertido. $\mathrm{O}$ autor demonstra como a criação de um paraíso perdido, esfera 
primitiva, original, e definitivamente perdida, faz parte da forma como a modernidade reage a suas próprias contradições. Tanto no México como no Brasil, esse paraíso se encontra no passado agrário, mito que fundamenta a constituição da cultura nacional. A invenção desse éden mítico tem um caráter dúbio: por um lado, produz sentimentos de culpa por causa da eliminação desses universos locais - como se observa na fala do escritor regionalista citada acima - por outro, participa da constituição da imagem coesionadora e ordenadora da nacionalidade moderna. É por esse segundo elemento que as formas culturais daí resultantes são freqüentemente associadas aos ideários políticos mais conservadores, o que demonstra seu caráter de anti-utopia, como designa Bartra: uma vez definida a verdadeira essência nacional, fica desautorizado qualquer projeto alternativo que pretenda transformar a sociedade de forma radical.

O brasileiro, como o mexicano, passam a ser definidos, portanto, como seres essencialmente primitivos e bárbaros, que estabelecem uma relação trágica com a modernidade. Se a modernização é não só necessária e desejável como também inevitável, os movimentos nacionalistas empreendem a busca do sentido de comunidade que foi perdido, ao mesmo tempo em que alimentam estereótipos que denunciam seu profundo desprezo pelo corpo social que o $[\mathrm{s}]$ sustenta, demonstrando uma concepção de desajuste entre realidade e projeto social, entre a índole do povo primitivo e arcaico e os imperativos de uma sociedade modernizada (BARTRA, 1987, p. 34 e 124).

O que marca de forma decisiva o exotismo na literatura brasileira é, portanto, o distanciamento: do romântico que busca inspiração numa natureza idealizada, livre de mosquitos e sezões, espaço a ser exaltado e colecionado, mas onde não cabe a reflexão transformadora; do crítico que atribui ao estilo brasileiro as virtudes da emoção, em detrimento da racionalidade, reforçando a definição da identidade americana por oposição à européia; do regionalista que observa com olhos de etnógrafo o mundo prémoderno, um mundo pitoresco, primitivo, que cabe saber conservar nos livros, não na realidade. Se o alheamento do escritor em relação à realidade é a tônica desse discurso exótico e nacionalista, há uma transformação nítida do exótico romântico, em sua exaltação entusiástica da natureza, ao exótico naturalista, meio nostálgico, meio galhofeiro. O olhar se volta para dentro do corpo nacional, suas fissuras, desvios e desníveis, a partir dos quais se estabelece a visão do país dual tão característica do pensamento brasileiro a partir de então. Os cultuadores da diferença abandonam a visão unificada de um Brasil por excelência, e se dirigem aos agonizantes universos rurais. Fadados a perecer, deve caber a eles ainda um lugar em nossa memória, e a difícil missão de, no redemoinho das transformações da vida moderna, guardar nossa verdadeira identidade. É o que nos lembra a personagem de Monteiro Lobato: “- Somos todos aqui uns pulhas, uns seixos rolados, dizia-me Crispim Paradela. Sabe o que é seixo rolado? Essas pedras de fundo de rio que, de tanto baterem umas nas outras, acabam sem arestas. A civilização nos iguala, nos arredonda, nos tira a coragem da originalidade. Ah, meu avô Paradela..." (LOBATO, 1974/1923, p. 114). 


\section{Bibliografia}

ABREU, João Capistrano de. Correspondência de Capistrano de Abreu. v. 1. Brasília, Editora da Universidade de Brasília, 1963.

ARARIPE Jr. "Estilo tropical. A fórmula do naturalismo brasileiro (1888)". In Araripe Jr. Teoria, crítica e história literária. São Paulo, Edusp, 1978.

"Sílvio Romero polemista". In Araripe Jr. op. cit.

ASSIS, Joaquim Maria Machado de. "Notícia da atual literatura brasileira". Instinto de nacionalidade (1873). In Crítica literária. São Paulo, W. Jackson, 1955.

AZEVEDO, Álvares de. Macário (1855). Belo Horizonte, Itatiaia, 1984.

BARTRA, Roger. La jaula de la melancolía. Identidad y metamorfosis del mexicano. México, Grijalbo, 1987.

BENDIX, Reinhard. Construção nacional e cidadania. Estudos de nossa ordem social em mudança. Trad. Mary Amazonas Leite de Barros. São Paulo, Edusp, 1996.

BOMFIM, Manoel. A América Latina. Males de Origem (1905). Rio de Janeiro, Topbooks, 1993.

CANDIDO, Antonio. Formação da literatura brasileira. v. 2. $6^{\mathrm{a}}$ edição. Belo Horizonte, Itatiaia, 1981.

O método crítico de Sílvio Romero. São Paulo, Edusp, 1988.

CARVALHO, José Murilo de. Brasil 1870-1914: a força da tradição. Rio de Janeiro, (mimeo), 1991.

CARVALHO, Maria Alice Rezende de. "República Brasileira: viagem ao mesmo lugar". In Dados. Revista de Ciências Sociais. Rio de Janeiro, (32) n 3, p. 303 a 321, 1989.

CUNHA, Euclides da. Contrastes e confrontos (1907). $5^{\text {a }}$ ed. Porto, Companhia Portuguesa Editora, 1919.

GALVÃO, Walnice Nogueira. Saco de gatos. São Paulo, Duas Cidades/Secretaria de Cultura, Ciência e Tecnologia, 1976.

GERBI, Antonello. O Novo Mundo. História de uma polêmica (1750-1900). Trad. Bernardo Joffily. São Paulo, Companhia das Letras, 1996.

LIMA, Luís Costa. O controle do imaginário. Razão e imaginação no Ocidente. São Paulo, Brasiliense, 1984.
LOBATO, José Bento Monteiro. "O avô do Crispim (1923)". In Cidades Mortas. 16a ed. São Paulo, Brasiliense, 1974.

LÖWY, Michel, SAYRE, Robert. Revolta e melancolia: o romantismo na contramão da modernidade. Trad. Guilherme João de Freitas Teixeira. Petrópolis, Vozes, 1995.

MIGUEL-PEREIRA, Lúcia. Prosa de ficção (de 1870 a 1920). $2^{\mathrm{a}}$ edição. Rio de Janeiro, José Olympio, 1957.

MURARI, Luciana. Brasil, ficção geográfica. Ciência e nacionalidade no país d'Os sertões. (dissertação de mestrado). Belo Horizonte, 1996.

RAMA, Angel. A cidade das letras. Trad. Emir Sader. São Paulo, Brasiliense, 1985

RANGEL, Godofredo. Vida Ociosa (1917). $2^{\text {a }}$ ed. São Paulo, Cia. Editora Nacional, s/d.

ROMERO, Sílvio. História da literatura brasileira (1888). $3^{\mathrm{a}}$ ed. aumentada. v. 1. Rio de Janeiro, José Olímpio, 1943.

SCHWARCZ, Lilia Moritz. O espetáculo das raças. Cientistas, instituições e questão racial no Brasil (1870-1930). São Paulo, Companhia das Letras, 1993.

SEVCENKO, Nicolau. Orfeu extático na metrópole. São Paulo, sociedade e cultura nos frementes anos 20. São Paulo, Companhia das Letras, 1998.

SÜSSEKIND, Flora. O Brasil não é longe daqui. São Paulo, Companhia das Letras, 1990.

THEODORO, Janice. "Visões e descrições da América. Alvar Nunez Cabeça de Vaca (XVI) e Hercules Florence (XIX)". In Revista Usp, São Paulo (30), p. 74-83, junho/agosto 1996.

TODOROV, Tzvetan. Nous et les autres. La réflexion française sur la diversité humaine. Paris, Editions du Seuil, 1989.

VENTURA, Roberto. Estilo tropical. História cultural e polêmicas literárias no Brasil, 1870-1914. São Paulo, Companhia das Letras, 1991.

WEHLING, Arno. A invenção da história. Estudos sobre o historicismo. Rio de Janeiro, Editora da Universidade Gama Filho; Niterói, Editora da Universidade Federal Fluminense, 1994.

Endereço da Autora: Rua Atalaia, 85 - Caiçara - Belo Horizonte - Minas Gerais - CEP 30.770-470 - Tel.: (0xx) 31 462-5591 - E-mail: fmurari@joinnet.com.br 